\title{
Debris flow rainfall thresholds in Val Canale Valley: first steps into their redefinition
}

\author{
C. Calligaris, L. Zini \& F. Cucchi \\ Department of Mathematics and Geosciences, University of Trieste, Italy
}

\begin{abstract}
Debris flows can be considered as highly hazardous hydrological processes very common in the whole Alpine environment, such as in the Friuli Venezia Giulia Region located in the extreme northeastern side of Italy. The progressive increase in socio-economic activities during these last years has created, in the mountain regions, the potentiality for an increased risk related to this kind of destructive phenomena. After the critical alluvial event which occurred on 21-22 June 1996 in the Fella watershed and the alluvial event of 29th August 2003 in the Val Canale valley when more than $293 \mathrm{~mm}$ of rain were recorded by Pontebba's rain-gauge in four hours (the total influx of the meteorological event, which lasted about $12 \mathrm{~h}$ was equal to $389.6 \mathrm{~mm}$ ) the need arose to deeply investigate the interpretation of the rainfall thresholds and on their redefinition. The analyzed examples show that there is a considerable increase in the intensity of the rainfall with a duration equal to or less than 24 hours. Above all - very critical for debris flow - are the rains of 1 to 6 hour duration having an intensity greater than $50 \mathrm{~mm} /$ hour.
\end{abstract}

Keywords: debris flow, rainfall thresholds, Val Canale valley.

\section{Introduction}

Debris flow phenomena are processes that frequently develop in an alpine environment and are considered one of the most dangerous and devastating due to their velocity and destructive capacity (Marchi [1]; Sosio et al. [2]; Calligaris and Zini [3]; Calligaris et al. [4]): the landslide phenomena may involve areas extending to $80-90 \mathrm{~km}^{2}$ (Slaymaker [5]).

The Val Canale Valley, located in the extreme northeastern part of Italy, has been repeatedly affected during the last century by debris flow phenomena 
creating serious economic and social damage. From the geological point of view, in the valley, are widely outcropping Sciliar dolostone and Werfen sandstones and shales. It is possible to individuate these rocks also in the hydrographic left of the Fella River set, in turn, along one of the major regional thrust: the FellaSava one (Figure 1) on which the Val Canale Valley was formed.

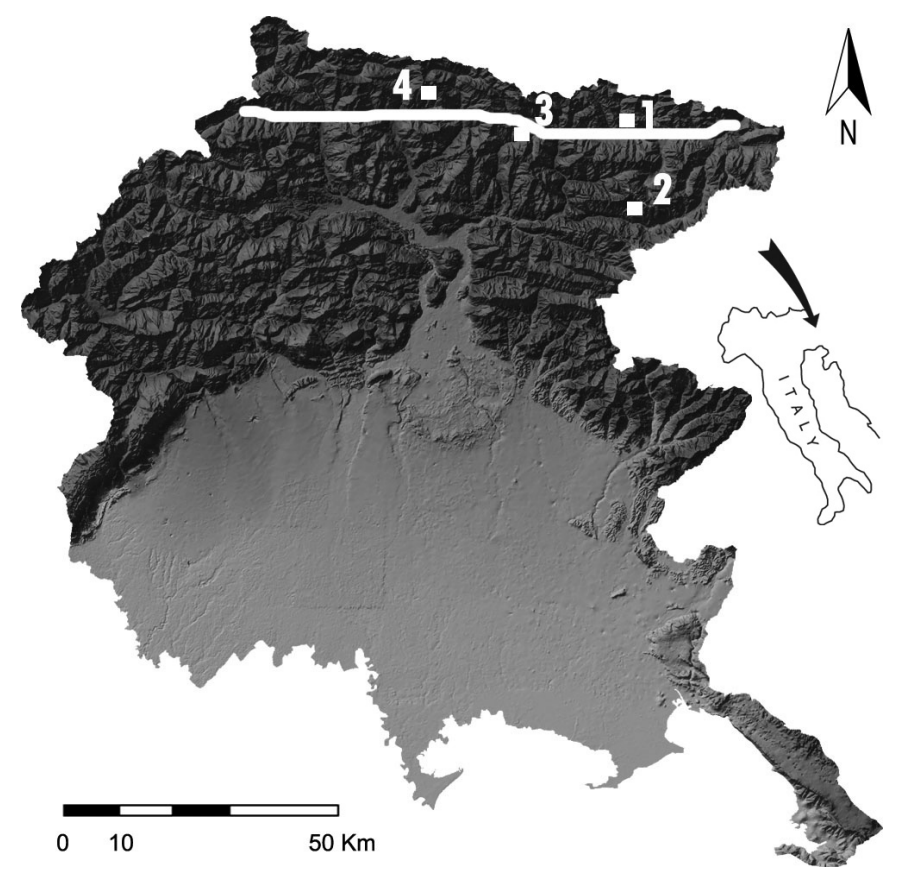

Figure 1: Friuli Venezia Giulia Region: 1) Malborghetto - Ugovizza and Mount Cucco; 2) Mount Lussari; 3) Pontebba and 4) Paularo. In white, sectioning the region, the Fella-Sava thrust.

In 2003, during an intense alluvial event, the Val Canale Valley was severely affected by debris flow phenomena. The valley is rather narrow, the angle of the slopes and the intense tectonic grade created the conditions for the existence of the predisposing and triggering factors as preconditions for the development of the instability phenomenon.

This event, definitely intense, caused the reactivation of old landslide and debris flow phenomena, but also produced a new hyperconcentrated phenomenon later transformed into debris flow leading to downstream debris, mud, rocks and pieces of wood.

Tropeano et al. [6] estimated that, in about 1 million of cubic meters, the total amount of debris and sediments mobilized and deposited during the event.

The alluvial event of 29th August 2003 produced huge changes in the morphologies of the invested areas causing important gullies and widening the riverbeds (Borga et al. [7]). 
Debris flow swept away houses and roads isolating, for days, the municipalities of Ugovizza, Valbruna, Malborghetto and Pontebba.

This alluvial event has not been the only one occurring in this area. In earlier times, on 21-22 June 1996, another important event caused severe damage to the entire Fella river basin area.

During the last recent years, on 15th August 2008, 4th September 2009 and 19th June 2011, smaller alluvial events have occurred creating severe damage to the infrastructures, traffic and houses. These events show that the critical hydrogeological conditions in the mountain area of Friuli Venezia Giulia Region have occurred more and more frequently in the last years and need to be better studied in order to avoid future disasters.

The aim of the present paper is to describe the results of a study on the heavy rainfalls occurring in the Fella basin in order to better define the triggering conditions of debris flow phenomena.

\section{Intense rainfalls in the Fella river basin and return times}

The north-east sector of Friuli Venezia Giulia Region, especially the Val Canale Valley, Canal del Ferro and Val Aupa, have often been affected by intense and destructive alluvial events (Paronuzzi et al. [8]). Paronuzzi, in his study, analyzed the alluvial events from 1925 to 1996 . The authors are focusing on the events which occurred from 2003 to present with some comparison with the past.

On 29th August 2003, harsh rainfalls characterized by high intensity started from twelve o'clock (Table 1).

Table 1: Rainfall depth and duration recorded by Pontebba's rain gauge (modified from Norbiato et al. [9]).

\begin{tabular}{|c|c|c|}
\hline Duration [hours] & \multicolumn{2}{|c|}{ Rainfall depth [mm] } \\
\hline & Pontebba (1996) & Pontebba (2003) \\
\hline 1 & 78.4 & 88.6 \\
\hline 3 & 155.0 & 233.4 \\
\hline 6 & 199.6 & 343.0 \\
\hline 12 & 345.6 & 389.6 \\
\hline 24 & 465.0 & 396.2 \\
\hline
\end{tabular}

Rainfall began to affect the high mountain zones between Mount Cucco and the mountain retreats of Malborghetto and Ugovizza, and later moved downstream with gradually increasing intensity (Figure 1).

The Pontebba rain gauge that is part of the rainfall's monitoring network belonging to the Regional Directorate of the Civil Defence, has been the only instrument, close to the study area, that worked regularly during the alluvial event.

The size of the event recorded by the Pontebba's rain gauge indicates the extreme gravity of the phenomenon. Since 1928 - the start of the recordings of the rainfall data - there had never been an event of such intensity. In the considered time range (from 1928 to 2012), the only comparable event was one 
which occurred on 22nd June 1996, when 78.4, 155, 199.6345 .6 and $465 \mathrm{~mm}$ of rain fell in 1, 3, 6, 12 and 24 hours respectively. What is clear from the recorded data, is that the event of 2003 reached considerable values of precipitations mainly in the range between 3 and 12 hours. Specifically were observed maximum values of $50.8 \mathrm{~mm}$ for 30 minutes (between 17 and 17.30), of $88.6 \mathrm{~mm}$ for 1 hour (15.30-16.30), of $233, .4 \mathrm{~mm}$ for 3 hours (14.30-17.30) and of $343.0(12.00-18.00)$ for 6 hours. The total amount of the rainfall, which lasted about 12 hours, was equal to $389.6 \mathrm{~mm}$. If comparing these data with the historical series of intense rainfalls recorded by Pontebba's rain gauge and elaborated using the Gumbel distribution, the rainfalls of 29th August 2003 can be associated with a return time greater than one hundered years. Particularly impressive are the values corresponding to the duration of 3 and 6 hours. The strong intensity detected appeared in agreement with the great intensity of the morphodynamic actions induced by this event (Norbiato et al. [9]; Calligaris et al. [10]). The greater part of the gravitational phenomena was triggered between 14 and 18 when the Pontebba rain gauge recorded a total amount of water equal to $293 \mathrm{~mm}$. To the north of the Pontebba-Ugovizza's alignment occurred circumscribed bursts having values greater than $400 \mathrm{~mm}$ (Borga et al. [7]).

Borga's researches (2005) on rain-probability thresholds lines obtained by the method of linear moments and the GEV (Generalized Extreme Value) method for the north eastern side of Italy recognized the statistical rarity of the rainfall that, in Val Canale, generated the flood of 29th August 2003.

The 2003 event, having characteristics of extraordinary, is not representing an isolated event in the context of the regional climatology: the magnitude of the event is in fact comparable to the one that characterized by other events which occurred in the previous 20 years and verified on 11th September 1983 with the center in Paularo and on 22nd June 1996 developed along the alignment among Moggio Udinese, Pontebba and Paularo.

These observations underline that extreme events are really rare if related to the specific site, while are quite frequent if the mountain territory regional area is considered.

In Borga's paper were estimated the rainfall's return times related to the event of 29th August 2003 at Pontebba. Return times characterizing the event varying considerably with the duration of the precipitations: for durations included between 1 and 24 hours, the return time is between 25 and 100 years; for 12 hours, it is between 200 and 500 years, while for duration between 3 to 6 hours, the return time has been calculated to be between 500 and 1000 years (Borga et al. [11]; Zanon [12]; Boniello et al. [13]).

In the graphs, two (Malborghetto and Pontebba) of the three rain-gauges present in the area, recorded high values of rainfall on 29th August 2003. Val Ugovizza station was installed after the alluvial event of 2003 and for this reasons there are no data available concerning this event.

After the event of 2003, three new smaller events occurred during which debris flow phenomena were recorded. One was on 15th August 2008 with 192.4 $\mathrm{mm}$ of rainfall in $12 \mathrm{~h}$, and $216,0 \mathrm{~mm}$ in the $24 \mathrm{~h}$. The second was on 4th September of 2009 with $74.0 \mathrm{~mm}$ of rainfall in $12 \mathrm{~h}$ and 109,4 in the $24 \mathrm{~h}$. The 

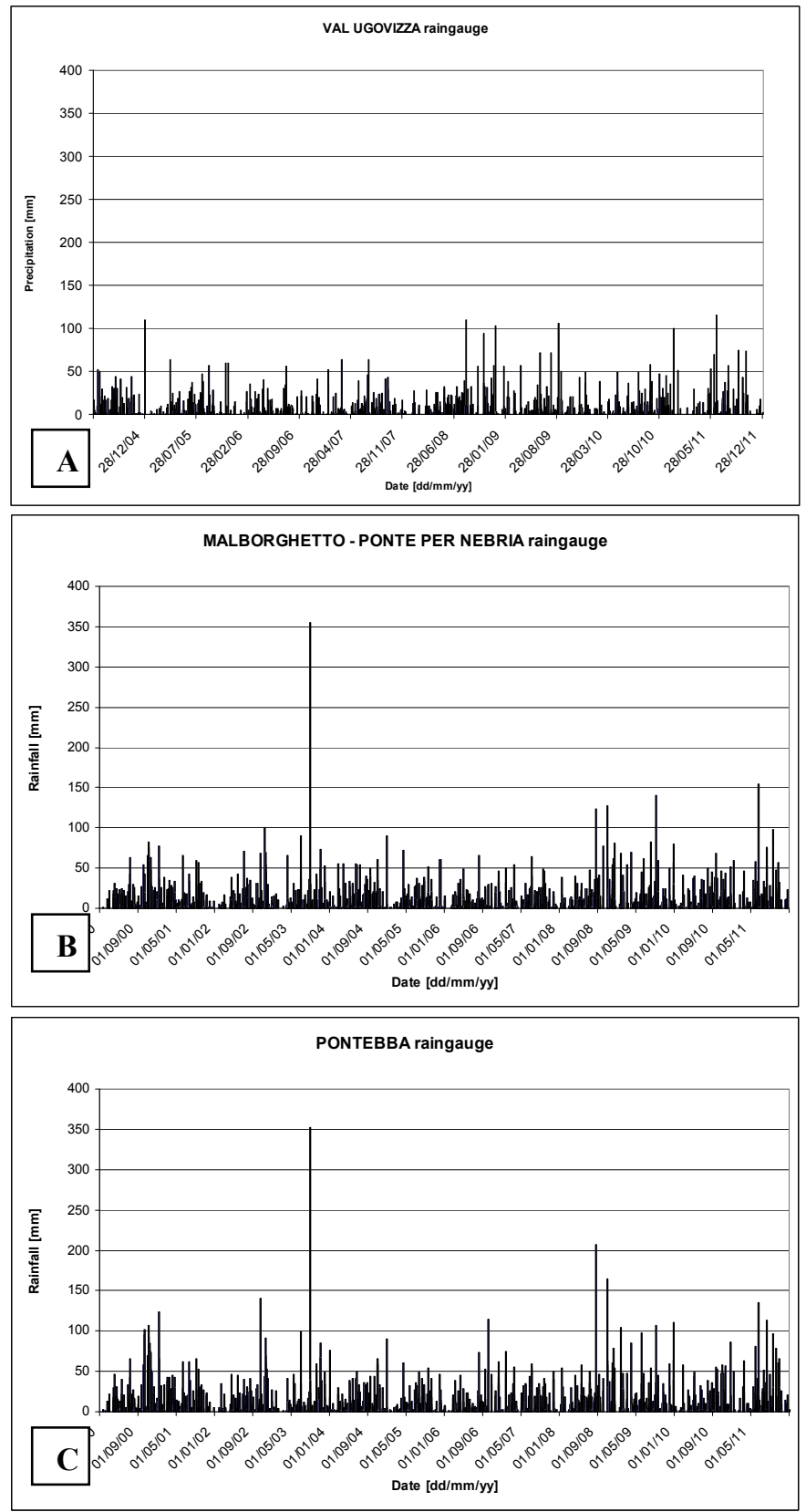

Figure 2: Daily rainfall data series recorded at the rain-gauges of Val Ugovizza (A), Malborghetto Ponte per Nebria (B) and Pontebba (C). The graphs presented are an extract of the series of data ranging from 1915 to 2011 . 


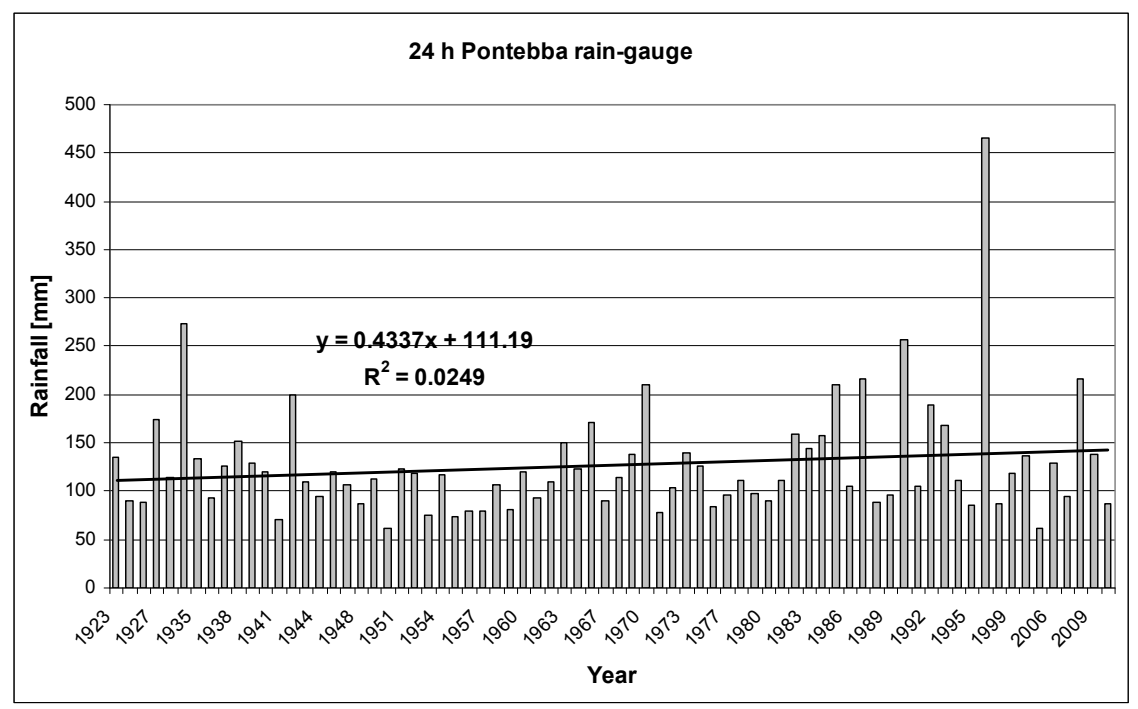

Figure 3: The increasing trend for the precipitations in the 24 hours for the Pontebba's rain-gauge station. The series studied is ranged between 1923 and 2011.

last event recorded in the valley dates 19 th June 2011 with $127,6 \mathrm{~mm}$ of rainfall in $12 \mathrm{~h}$ and 134,8 in $24 \mathrm{~h}$.

\section{Rainfall thresholds}

Talking about rainfall heavy conditions, the scientific community is still defining hydrological models on statistic base finalized to identify the critical amount of rain and the thresholds over which the triggering risk, for a debris flow phenomena, can be considered very high. In this context, data related to the hourly recordings are used to determine the critical combination of intensityduration, responsible of the triggering of a debris flow phenomena (Calligaris et al. [14]; Rapelli [15]).

A generic critical precipitation curve can be defined by the following empirical equation:

$$
\mathrm{I}=\mathrm{a} \mathrm{D}^{\mathrm{b}}
$$

where $I$ is the average rainfall intensity $(\mathrm{mm} / \mathrm{h})$ and $\mathrm{D}$ is the duration of the rainfall (hours). a and b are empirical coefficients (Bruschi [16]). For the Friuli Venezia Giulia Region, the only values of $a$ and $b$ have been obtained by Paronuzzi et al. [8] but they not take into account the recent alluvial events of 2003, 2008, 2009 and 2011.

For the Val Canale valley and especially for Pontebba rain-gauge, the values of the empirical parameters have been calculated for the events occurred between 1985 and 2011. 


\section{Results and conclusions}

The analysis of the historical data series recorded by Pontebba rain-gauge station permitted to redefine the triggering thresholds curves for some of the debris flow phenomena occurring in the Val Canale valley and specifically in the areas close to Malborghetto and Ugovizza municipalities. The inferior limit curve is defined by the curve obtained in the graph of Figure 4 for the event of 2011; to this triggering intensity value, is possible to associate a and b empirical coefficients. From eqn. (1) it is possibile to obtain

$$
\mathrm{I}=26.783 \mathrm{D}^{-1.296}
$$

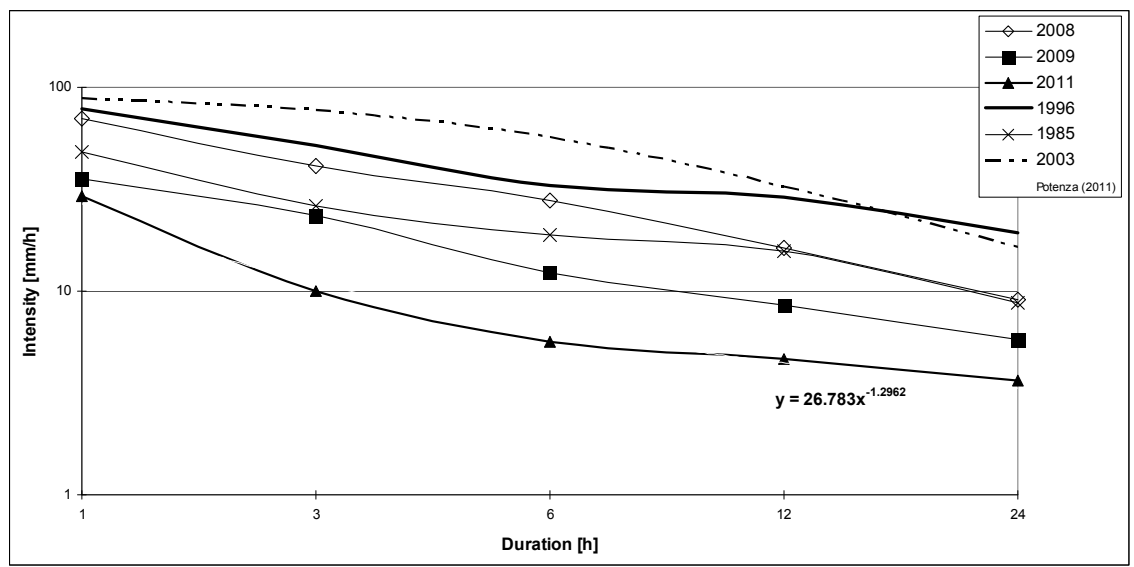

Figure 4: Triggering thresholds curves for debris flows calculated for the Pontebba rain-gauge station in the period between 1985 and 2011.

The calculated limit values of the coefficients a and b can be compared with the ones defined for the same area or for other areas of the Alpine region.

Cancelli and Nova [17] proposed, for the Austrian Alps and for the Valtellina areas values of $a=44,67$ and $b=-0,78$, while Paronuzzi, for the Val Canale valley, analyzing the data until 1996, obtained for a, a value of 47.742 and for b a value of -0.507 .

The differences between the calculated numbers could depend on the differences in permeability characteristics of the land surfaces and from the different regime of precipitations typical of the mountain areas. The different precipitation curves are distributed with a similar behaviour inside a field characterized by a progressively increasing instability. From the data analysis emerges that during recent years, a progressively decrease in the amount of rainfall can anyway trigger debris flow phenomena. The identified field of hydrogeological instability is bound below by the precipitations occurring at the Pontebba rain gauge station on 19th June 2011 and above by the ones which fell on 29th September 2003. 
This type of approach, based on an integrated study of rainfall data and on debris flow events, can be useful for the characterization of a regional instability threshold and this can be considered to be the goal for future analyses.

\section{Acknowledgements}

The authors are grateful to Alberto Deana and his team (Regione Autonoma Friuli Venezia Giulia - Direzione Centrale Ambiente, Energia e Politiche per la Montagna - Servizio Idraulica) for the rainfall data availability and to Dott. Stefanelli Nicola (Civil Defence of Friuli Venezia Giulia Region) for the information regarding the occurrence of debris flow phenomena.

\section{References}

[1] Marchi, L., Il trasporto solido di fondo e le colate detritiche: fenomenologia ed effetti sull'assetto dei corsi d'acqua a forte pendenza, Pubblicazione del corso in cultura dell'ecologia, Atti del $41^{\circ}$ Corso, Università di Padova, 126-139, 2005.

[2] Sosio, R., Crosta, G. B., Valbuzzi, E., Caratterizzazione reologica e modellazione numerica di un debris flow in ambiente alpino, Giornale di Geologia Applicata, 3, 263-268, 2006.

[3] Calligaris, C. and Zini L., Debris flow phenomena: a short overview, Book chapter, in: Earth Sciences ISBN 978-953-307-672-0, Ed. Imran Ahmad Dar, INTECH (Croatia), 71-90, 2012.

[4] Calligaris, C., Cucchi, F., Nicola, G., Zini, L., Kranitz, F., Manca, P., Modellazione della colata detritica del Rio Ruscis (Val Pontebbana), Rassegna Tecnica del Friuli Venezia Giulia, Vol.4, 25-29, 2009.

[5] Slaymaker, O., The distinctive attributes of debris torrents, Hydrol. Sci; 33, 567-573, 1988.

[6] Tropeano, D., Turconi, L., Sanna, S., Debris flows triggered by the 29th August 2003 cloudburst in Val Canale, eastern Italian Alps, Proc. Int. Symp. Interpraevent 2004, Rova del Garda, Italy, 121-132, 2004.

[7] Borga, M., Dalla Fontana, G., Vezzani, C., Regional rainfall depthfrequency equations for an Alpine Region, Natural Hazards, 36, 221-235, 2005.

[8] Paronuzzi, P., Coccolo, A., Garlatti, G., Eventi meteorici critici e debris flows nei bacini montani del Friuli, ACQUA - Sezione I/Memorie Idrogeologia, 39-50, 1998.

[9] Norbiato, D., Borga, M., Sangati, M. and Zanon F., Regional frequency analysis of extreme precipitation in the eastern Italian alps and the August 29, 2003 flash flood, Journal of Hydrology, 345, 149-166, 2007.

[10] Calligaris, C., Zini, L., Kranitz, F., Manca, P., Delimitazione delle aree a rischio da colate detritiche in Friuli Venezia Giulia, in proceedings of: SIGEA 2011, 2012. 
[11] Borga, M., Boscolo, P., Zanon, F., Sangati, M., Hydrometeorological analysis of the 29 August 2003 flash flood in the eastern Italian Alps, Journal of Hydrometeorology, 1049-1067, 2007.

[12] Zanon, F., Radar Hydrology and flash flood event analysis, Tesi di dottorato inedita, Dipartimento Territorio e Sistemi Agro Forestali (TESAF) CICLO XXII, 180, 2010.

[13] Boniello, M.A., Calligaris, C., Lapasin, R., Zini, L., Rheological investigation and simulation of a debris flow event in the Fella watershed, Natural Hazard Earth System Sciences, 10, 1-9, 2010.

[14] Calligaris, C., Boniello, M., A., Zini, L., Debris flow modelling in Julian Alps using FLO-2D, in: Monitoring, Simulation, Prevention and Remediation of Dense and Debris Flows, Ed. Lorenzini, G., Brebbia, C. A., and Emmanouloudis, D. E., Southampton, WIT Press, 60, 81-88, 2008.

[15] Rapelli, F., Definizione delle soglie pluviometriche d'innesco di frane superficiali e collate torrentizie: accorpamento per aree omogenee, Istituto Regionale della Ricerca in Lombardia (IReR), 125, 2008.

[16] Bruschi, A., Colate detritiche - Stima del percorso e della pericolosità, Dario Flaccovio Editore, ISBN 978-88-7758-801-2, Palermo, Italy, 2008.

[17] Cancelli, A., and Nova, R., Landslide in soil debris cover triggered by rainstorms in Valtellina (Central Alps - Italy), Proc. IV Int. Conf. on Field Workshop on Landslides, Tokyo, 267-272, 1985. 